\title{
Penerapan Prinsip Good-Enviromental Governance di Kabupaten Serang (Studi Kasus : Sungai Cidurian Kabupaten Serang)
}

\section{Anggita Amilia Purnama ${ }^{1}$}

Ilmu Pemerintahan, Universitas Sultan AgengTirtayasa amiliaanggita@gmail.com

\section{Dzikra Chelonia ${ }^{2}$}

IlmuPemerintahan, Universitas Sultan AgengTirtayasa dzikra.chelonia91@gmail.com
E-ISSN (2721-0642)

Recieved:

June 102020

Revised:

December 112020

Accepted:

December 142020

Doi Number

https://doi.org/10.37950/ijd.v2i3.56

\section{Abstract}

The environmental pollution in the Cidurian River is caused by the disposal of factory waste which dumps waste carelessly into the river, this makes the water in the Cidurian River polluted by the factories that are around the cidurian river, in this problem it appears that these factories does not protect the environment well. This research uses a qualitative method with a descriptive approach. The Serang District environmental office has implemented Good Environmental governance and has issued policies regarding anyone who does not protect the environment and will receive a reprimand and other laws that have been set. This study aims to explain that in policies related to the environment, it is based on Good Environmental Governance.

Keywords: cidurian, river, waste. environmental governance

\begin{abstract}
Abstrak
Pencemaran lingkungan yang ada di Sungai Cidurian disebabkan oleh adanya pembuangan limbah perusahaan yang mencemarkan sungai dengan membuang limbah secara sembarangan ke sungai, hal ini membuat air yang ada di Sungai Cidurian tercemar oleh pabrik-pabrik yang ada disekitaran sungai cidurian, dalam permasalahan ini terlihat bahwa pabrik-pabrik tersebut tidak menjaga lingkungan sekitar secara maksimal. Riset yang kami teliti menggunakan sebuah pendekatan kualitatif deskriptif. Dinas lingkungan hidup Kabupaten Serang ini sudah menerapkan
\end{abstract}


Good Environmental Governance serta telah mengeluarkan kebijakan-kebijakan mengenai siapapun yang tidak menjaga lingkungan maka akan mendapat teguran dan hukum lainnya yang sudah ditetapkan. Penelitian ini bertujuan unttuk menjelaskan bahwa dalam kebijakan yang berkaitan tentang lingkungan hidup, didsarkan pada Good Enviromental Governance.

Kata kunci : cidurian, sungai, limbah. tatakelola lingkungan

\section{Pendahuluan}

Enviromental Governance menjadi suatu hal yang penting dalam tata kelola pemerintahan di Kabupaten Serang karena Enviromental Governance merupakan asas dalam pemerintahan untuk menjadikan sebuah pemerintahan menjadi good governance terutama dalam pengelolaan lingkungan karena pengelolaan lingkungan yang baik merupakan dasar dari adanya pemerintahan yang baik. Pemerintahan Kabupaten Serang dianggap belum tegas dalam menangani pencemaran lingkungan yang ada di Kabupaten Serang, hal ini dapat diketahui dengan banyaknya pabrik-pabrik yang mencemari lingkungan di Kabupaten Serang sehingga menyebabkan pencemaran lingkungan yang sulit diatasi. Pemerintahan Kabupaten Serangpun dirasa belum tegas dalam menyikapi permasalahan pencemaran lingkungan, kebijakan-kebijakan yang dibuatpun belum mampu mengatasi pencemaran lingkungan yang masih terjadi hingga saat ini.

Pencemaran yang diakibatkan oleh pabrik, berada di Sungai Cidurian, Kecamatan Kopo, Kabupaten Serang. Sungai ini tercemar diakibatkan oleh limbah yang didapatkan dari dua pabrik yang berada disekitaran Sungai Cidurian tersebut. Tercemarnya sungai ini membuat air sungai menjadi hitam dan bau, sehingga masyarakat tidak dapat menggunakan air tersebut ketika masyarakat membutuhkan air karena khawatir terkena penyakit gatal-gatal dan sebagainya. Aroma yang dihasilkan dari sungai tersebut mengganggu penciuman warga sekitar.

Sungai cidurian ini mengalir dari Bogor hingga ke Desa Sukamanah, Tirtayasa, Kabupatren Serang. Sungai ini mengalir cukup panjang, air yang dihasilkan oleh sungai ini jika terjadi kemarau airnya akan surut dan berwarna hitam sedangkan jika musim hujan air yang dihasilkan yaitu berwarna coklat kemerah-merahan hal tersebut diakibatkan oleh pencemaran yang dihasilkan dari sebuah pabrik tekstil yang ada di Cikande. Dalam hal ini tentu saja menjadi sebuah permasalahan bagi warga sekitar karena mereka selalu memakai air mengalir tersebut guna memenuhi kehidupan yang mereka jalani.

Adapun membersihkan tubuh, cuci baju, memasak dan kebutuhan lain nya, hal ini menjadikan sungai ini menjadi sangat berpengaruh bagi warga sekitar. Ketika air surut, air akan berubah warna menjadi hitam dan sangat mengganggu penciuman warga sekitar hal tersebut diakui oleh warga sekitar yang tinggal didekat Sungai Cidurian, ketika air surut masyarakat setempat tidak dapat menggunakan aliran air tersebut karena kondisi air yang surut serta memiliki bau yang sangat menyengat. Karena jika tetap digunakan tidak baik untuk tubuh dan kesehatan warga sekitar.

Saat air sungai mulai surut dan menghitam berkepanjangan maka warga sekitar memiliki ide untuk menggunakan air tersebut dengan cara melakukan penyulingan air yang dilakukan oleh salah satu warga. Penyulingan tersebut dilakukan untuk mengatasi air kotor tersebut agar bisa digunakan untuk kegiatan sehari-hari. Adanya 
penyulingan tersebut sangat membantu warga sekitar dalam mengatasi kebutuhan kebutuhan mereka. Ketika sungai Cidurian ini tercemar, maka mempengaruhi pasokan air di daerah sekitarnya.

Sungai Cidurian ini merupakan Sungai besar, pada saat tercemar sungai ini mempengaruhi pasokan air oleh PDAM, PDAM tidak bisa memberi pasokan air karena sungai ini sudah tercemar oleh limbah pabrik yang mencemari sungai tersebut. Selain mencemari sungai, air limbah inipun berdampak pada tambak ikan dan sawah warga. Hal ini berdampak pada masyarakat, ikan-ikan tersebut mati, sawah-sawah mati terkena limbah yang dihasilkan dari pabrik-pabrik. Hal ini menimbulkan kerugian bagi masyarakat sekitar terutama pada musim kemarau karena ketika musim kemarau air sulit didapatkan. Namun, ketika terdapat air justru air tersebut tercemar oleh limbah pabrik.

Hal seperti ini menurut warga sekitar sudah berlangsung lama, akan tetapi dari pihak pemerintah belum ada tindakan nyata untuk mengatasi permasalahan ini. Menurut warga sekitar, seharusnya dilakukan pengerukan sungai agar dan pemberdayaan sungai. Menurut warga, pemerintah hanya melakukan peneguran melalui surat yang diberikan kepada pihak pabrik yang mencemari sungai cidurian. Setelah pemberian surat teguran tersebut namun masih belum ada tindak lebih lanjut dr pabrik tersebut untuk mengurangi air limbah tersebut atau apapun hal lain nya.

Dalam hal ini terlihat jelas bahwa pemerintah belum seutuhnya turun kelapangan untuk mendatangi pabrik-pabrik yang mencemari Sungai Cidurian tersebut karena jika hanya melalui surat, hal itu dirasa tidak akan mefektif, harus adanya planning lebih lanjut untuk mengatasi permasalahan yang sangat prioritas ini karena melihat kehidupan waraga sekitar yang tinggal didekat sungai Cidurian. Dalam penerapan good governance harusnya dalam hal ini terdapat pengawasan yang lebih dari pemerintah dalam mengawasi pabrik-pabrik tersebut dalam pembungan limbah mereka.

\section{Kerangka Teori \\ Good Governance}

Pemerintahan dan tata kelola pemerintahan yang baik "good governance" semakin banyak digunakan oleh pemerintahan untuk menindaklanjuti permasalahan lingkungan. Pemerintah menggunakan teori ini sebagai bentuk pengelolaan dalam menentukan keputusan yang akan diterapkan atau mungkin keputusan tersebut tidak akan diterapkan. Jadi, pemerintahan yang baik adalah proses di mana organisisasi publik mengerjakan urusan dari tujuan organisasi tersebut, memberdayakan sumberdaya dan menjamin realisasi hak dan layanan (Caiden, 1994). Pemerintahan yang baik, menyelesaikannya dengan cara yang pada dasarnya bebas dari penyalahgunaan dan tindakan korupsi (KKN) serta dengan memperhatikan aturan hukum serta memperhatikan lingkungan yang memiliki dampak langsung untuk masyarakat (Maulana, 2020).

Tata pemerintahan yang baik dapat didefinisikan sebagai proses yang memandu hubungan politik dan sosial-ekonomi dengan komitmen terhadap nilai-nilai demokratis, layanan terpercaya dan bisnis yang jujur dan adil. Selain itu, good governance memiliki implikasi besar untuk kesetaraan, kemiskinan dan kualitas hidup (Kalsi \& Kiran, 2016). 


\section{Good Enviromental Governance}

Negara ibarat sebuah organisasi yang dapat mengatur kebijakan apa yang akan dikeluarkan maupun tidak. Oleh karena itu nasib kelestarian lingkungan dapat dilihat dari sejauh mana negara dapat konsisten terhadap nilai-nilai ekologis dalam membuat setiap kebijakan serta keputusan. Konsep enviromental Governance ini merupakan pola interaksi pemerintah terhadap masyarakat mengenai lingkungan hidup (Sawir \& Hafid, 2020). Peran negara sangat besar yaitu bukan hanya mengubah kondisi lingkungan akan tetapi memastikan perubahan terhadap kondisi ekologi.

Suatu aktivitas yang dimaksudkan untuk memberdayakan sumber daya alam secara bekelanjutan tanpa merusak kualitas sumber daya alam tersebut dan menjaga kualitasnya dapat diartikan sebagai Good Enviromental Governance. Interaksi terhadap lingkungan dilakukan oleh tiga kelompok yaitu negara, masyarakat, dan swasta. Untuk melaksanakan hal tersebut diperlukan adanya tranparansi dari lembaga lingkungan yang terkait, dalam menerapkan kebijakan yang dilakukan perlu melibatkan masyarakat untuk menetapkan penentuan kebijakan yang dicanangkan. Pada hakikatnya, pemerintahan harus menerapkan prinsip Good Enviromental Governance ini karena pemerintah memiliki tanggung jawab langsung terhadap masyarakat sehingga dalam melakukan kebijakan yang dibuat haruslah berdasarkan pada kepentingan masyarakat dan dampak terhadap lingkungan, manusia serta alam merupakan hal yang saling berkaitan dan saling membutuhkan (Hikmawan, Ika Indriyany, et al., 2019). Oleh karena itu kedua sumberdaya tersebut tidak dapat terpisahkan. Dalam konsep Governance, negara dan masyarakat dilihat sebagai objek dan subjek sehingga dikenal sebagai enviromental governance.

Untuk menerapkan konsep yang ada dalam Good Environmental Governance dalam prakteknya berdasarkan pada faktor-faktor penting yang terdapat dalam GEG, yaitu ketentuan hukum (rule of law), partisipasi dan representasi, cara mengakses terhadap informasi, transparansi dan akuntabilitas, desentralisasi, lembaga serta institusi serta proses dalam mendapatkan keadilan. Elemen rule of law ini digunakan agar pemerintah tidak bertindak sewenang-wenang dan menyalahgunakan kekuasaan tanpa memperhatikan keinginan publik. Aspek partisipasi dan representasi merupakan sebuah hal yang penting di dalam mewujudkan sebuah kebijakan. Partisipasi aktif maupun pasif dari masyarakat diharapkan mampu membantu menyukseskan pembangunan melalui penyuaraan aspirasi dan berkontribusi dalam proses pengambilan keputusan sesuai dengan masyarakat inginkan sehingga konflik antara negara dan masyarakat dapat diminimalisir (Hikmawan, Indriyany, et al., 2019). Selanjutnya, akses terhadap informasi. Pemerintah sebagai penyedia layanan informasi harus mampu memenuhi hak masyarakat dalam mengakses informasi, terutama yang berkaitan dengan lingkungan hidup.

Akses terhadap informasi lingkungan terkait sumberdaya misalnya, jarang diperhatikan oleh pemerintah sehingga masyarakat minim informasi terkini. Padahal saat ini merupakan era milenial dimana semua orang pasti memiliki gadget atau smartphone dan semakin sadar akan informasi. Elemen selanjutnya yakni transparansi dan akuntabilitas. Transparansi berkaitan dengan kejelasan kan keakuratan informasi, baik dalam proses perencanaan, pelaksanaan hingga evaluasi kebijakan tanpa ada yang ditutup-tutupi. Sedangkan akuntabilitas berkaitan dengan pertanggungjawaban yang ada dalam organisasi. Kedua aspek ini, transparansi dan akuntailitas kerap kali dikesampingkan oleh pemerintah. Tidak semua informasi yang dibagikan oleh 
pemerintah dapat dengan mudah diakses oleh masyarakat, seringkali banyak informasi yang tidak dicantumkan oleh pemerintah bahkan beberapa informasi tersebut cenderung tidak dapat dipertanggungjawabkan dengan jelas. Desentralisasi penting dilakukan kaitannya dengan pelestarian lingkungan. Negara memiliki kewenangan dalam hal mengelola semua sumberdaya alam yang ada di Indonesia. Desentraliasasi dapat diartikan sebagai penyerahan tugas pokok pemerintahan pusat ke pemerintahan daerah yang dilaksanakan sesuai dengan aturan-aturan yang telah berlaku. Hal ini menjadikan desentralisasi diharapkan mampu terlaksana dengan baik hingga ke tingkat yang paling bawah sekalipun. Karena pada prinsipnya, pemerintah daerah lebih mengerti serta memahami permasalahan yang terjadi di daerahnya sehingga pemerintahan daerah lebih mampu menghasilkan keputusan dan kebijakan yang tepat tanpa merugikan banyak pihak.

Desentralisasi dalam pengelolaan lingkungan hidup ditujukan untuk meningkatkan kualitas pelayanan akan akses informasi publik serta menyejahterakan masyarakat di tingkal lokal. Lembaga dan institusi (Solikhin, 2017). Kehadiran lembaga dan institusi diharapkan mampu menyeimbangkan kepentingan publik serta dapat mengartikulasikan suara masyarakat, menghasilkan informasi publik yang transparan dan akuntabel, serta menanggapi umpan balik dan memberikan pembelajaran untuk masyarakat daerah terkait cara menjaga kelestarian lingkungan guna mewujudkan good environmental governance (Mardiana, 2019).

\section{Metode Penelitian}

Penelitian ini memakai metode penelitian deskritif kualitatif hal ini karena menggambarkan suatu penelitian yang menuliskan suatu kebenaran ataupun suatu konflik yang ada pada fenomena yang terjadi di sungai Cidurian, Kabupaten Serang. Penelitian deskritif kualitatif merupakan suatu penelitian atau analisis yang menuliskan suatu peristiwa yang mempunyai konflik besar melalui objek penelitian berdasarkan apa yang peneliti lihat pada kejadian tersebut (Nawawi dan Martini 1996: 73). Suatu deskritif ini akan memaksimalkan suatu gambaran semua masalah dan keadaan yang memang benar-benar terjadi guna menyelesaikan penelitian Mukhtar (2013: 28).

Fokus penelitian kali ini adalah : (1) melihat Dinas Lingkungan Hidup Kabupaten Serang sudah menetapkan good governance dan good enviromental governance atau tidak, (2) pencemaran lingkungan di sungai Cidurian dilakukan oleh pihak-pihak siapa saja, (3) teguran apa saja yang dilakukan oleh pihak dinas terkait pihak yang sudah mencemari Sungai Cidurian, (4) kesesuaian antara hasil peran DLH dalam menerapkan good governance dan good enviromental governance.

Lokasi penelitian ini di Sungai Cidurian, Kecamatan Kopo, Kabupaten Serang, sungai yang tercemar air limbah ialah disekitaran Kecamatan Kopo. Pengumpulan data pada penelitian ini adalah dilakukan dengan observasi, dan wawancara, kemudian instrumen penelitian nya adalah catatan lapangan dan pedoman wawancara.

\section{Hasil dan Diskusi}

Kita sebagai mahluk hidup tentunya sangatlah memerlukan air dalam menjalani kehidupan ini, bahkan jika tidak ada air kitapun tidak akan bisa bertahan hidup, dari mulai minum, mandi dan sebagainya. Hal utama yang sangat penting ialah untuk minum karena tubuh kita sendiri pun sangat perlu untuk menjaga cairan dalam tubuh 
agar tubuh dapat sehat dan tidak berpenyakit. Tentunya, kita menginginkan keadaaan sehat supaya tidak merepotkan keluarga, teman dekat bahkan tidak merepotkan pemerintah. Dengan begitu sangatlah jelas bahwa kita sebagai masyarakat harus menjaga sumber daya yang ada dan memanfaatkan air dengan benar serta tidak mencemari atau mengotori air. Begitupun dengan air sungai, kita harus menjaga dan bahkan melastarikan agar air tersebut tidak kering, namun sekarang yang terjadi di Sungai Cidurian ini adanya penurunan sumber daya air bahkan air nya tercemar dikarenakan beberapa oknum yang mempunyai perusahaan dibidang bahan sehingga membuah limbah pabrik ke Sungai Cidurian.

Undang-Undang Nomor 32 Tahun 2009 tentang "Perlindungan dan Pengelolaan Lingkungan Hidup". Pada pasal (2) dijelaskan bahwa perlindungan dan pengelolaan lingkungan hidup adalah upaya sistematis dan terpadu yang dilakukan untuk melestarikan fungsi lingkungan hidup dan mencegah terjadinya pencemaran dan/atau kerusakan lingkungan hidup yang meliputi perencanaan, pemanfaatan, pengendalian, pemeliharaan, pengawasan, dan penegakan hukum.

Sektor industri bisa dikatakan sebagai tiang perekenomian di suatu daerah apabila pada sektor tersebut berjalan dengan baik sesuai potensi yang ada dan mendapatkan keuntungan bagi masyarakat untuk membantu meningkatkan perekonomian. Industri adalah bagian dari proses produksi, bahan-bahannya pun terdiri dan diambil seta didapatkan langsung dan tidak langsung, yang mengatur atau diproses agar hasil maksimal sehingga nilai harga jual akan tinggi. Pada perekonomian untuk rakyat, suatu rancangan kegiatan yang diolah juga dengan perindustrian yang telah diatur pada pasal 1 butir (2) Undang-Undang Nomor 3 Tahun 2014 tentang perindustrian, mengatakan bahwa industri merupakan suatu kegiatan ekonomi yang melakukan kegiatan pengolahan bahan mentah, bahan dasar, bahan setengah jadi, atau barang jadi sehingga barang tersebut memiliki nilai yang lebih tinggi dalam penggunannya sehingga dapat memberikan nilai yang lebih tinggi.

GEG (Good Environmental Governance) dalam prosesnya sebagai pelaku kepentingan terdapat tiga unsur good governance, yaitu pemerintah, swasta, dan masyarakat. Tiga hal tersebut sangat berpengaruh dalam rangka penciptaan pemerintahan yang baik. Pusat pemeritah tidak dapat menangani semua permasalahan tanpa hadirnya suatu ikatan melalui sektor perusahaan swasta dan rakyat, semua saling mendukung sehingga tercipta keharmonisan dan transparansi. Hubungan antara pemerintah dalam mengatasi pencemaran limbah industri pabrik mengarah pada prinsip untuk mewujudkan GEG. Good Environmental Governance merupakan suatu kelompok yang dikelola oleh pemerintah agar menyelesaikan permasalahan terhadap lingkungan secara tertib dan benar begitu juga harus mengedepankan prinsip-prinsip suatu pembangunan yang berjangka panjang, yang memperhatikan lingkungan. Jadi dalam hal ini sebuah perusahaan sebelum mendirikan usahanya harus mempertimbangkan segala aspek supaya tidak merusak sumber daya terutama tanah, air, udara karena telah ada badan pemerintahan yang mengawasi.

Suatu sumber daya air salah satunya adalah sungai, yang dimana sungai mempunyai banyak sekali manfaat bagi mahluk hidup disekitaran sungai, karena air merupakan unsur utama dalam kehidupan ini, maka dari itu harus menanamkan kesadaran akan menjaga lingkungan sekitar maupun sungai sekitar agar tidak disalah gunakan oleh oknum-oknum yang tidak bertanggung jawab yang tidak mencintai 
lingkungan. Maka sungai harus dijaga selalu, menurut (Joko Subagyo;1992) hal tersebut dapat dilakukan dengan cara :

1. Dijaga agar sumber air tidak kering.

2. Ditanamkan pemukiman, perdagangan, industri, perhubungan, perkantoran, pariwisata dan sebagainya secara jelas akan meningkat secara drastis maka perubahan pemakaian lahan akan mempengaruhi kualitas air sungai sehingga akan berubahnya sungai, baik itu alirannya atau airnya, begitupun kualitas sumber daya air sungai itu sendiri berdasarkan fungsi serta kebermanfaatannya.

3. Ditanamkan agar masyarakat dapat mengendalikan diri nya untuk tidak merusak lingkungan.

Sumber daya air jika tidak dirawat dan dilestarikan dengan baik maka akan menyusahkan semua orang. Maka dari itu, sungai perlu dijaga dari hal yang kecil sampai hal yang besar agar sungaitetap terjaga kelestariannya dengan baik, terutama di sepanjang aliran sungai Cidurian. Sungai Cidurian mempunyai sumber manfaat penting untuk semua kebutuhan antara lain ; sumber air bersih, dan titik kehidupan masyarakat sekitar.

Dengan banyaknya usaha yang bersaing tentu diperlukan peningkatan kesejahteraan bagi rakyat. Adanya perluasan wilayah untuk memenuhi pemenuhan kebutuhan yang dibutuhkan seperti sarana pemukiman, perdagangan, industri, perhubungan, perkantoran, pariwisata dan sebagainya secara jelas akan meningkat secara drastis, maka perubahan pemakaian lahan akan mempengaruhi kualitas air sungai sehingga akan menyebabkan perubahan bagi sungai, baik itu alirannya, airnya bataupun kualitas sumber daya air sungai itu sendiri.

Dinas Lingkungan Hidup (DLH) Kabupaten Serang mencatat sejak awal Januari hingga 25 Maret 2019 sudah terjadi 13 kasus pencemaran lingkungan di wilayahnya. Jumlah tersebut tersebar di wilayah Serang Barat dan Timur dengan berbagai kasus mulai dari limbah cair hingga udara. Dari hal ini dapat diketahui bahwa telah terjadi penecemaran lingkungan di wilayah Serang. Hal ini patut untuk dijadikan perhatian oleh pemerintah setempat karena hal ini sangat berdampak terhadap lingkungan. Sebuah konflik yang terjadi antara pemerintah Kabupaten Serang yaitu Dinas Lingkungan Hidup yang menaungi sungai Cidurian ini dengan para pengusahapengusaha yang mendirikan suatu pabrik didekat lingkungan sungai tentunya menimbulkan beberapa dampak yang terjadi, tentunya dampak tersebut sangat dirasakan oleh masyarakat setempat maupun pihak dinas terkait karena Sungai Cidurian akan terus tercemar jika pihak perusahaan tidak menerapkan aturan yang diberikan oleh dinas lingkungan hidup, karena limbah yang dibuang akan mempengaruhi kerusakan pada kualitas air. Tentunya, air akan menghitam dan tidak jernih lagi. Karena yang masuk kedalam air ini adalah bahan kimia berbahaya maka dari itu, hal tersebut sangat mempengaruhi kualitas air, dan jika sungai Cidurian ini kualitas airnya sudah sangat memprihantinkan maka dapat membahayakan masyarakat yang masih menggantungkan kesehariannya pada sungai Cidurian.

Pencemaran ini terjadi di sungai Cidurian dikarenakan banyak aktivitas warga yang dilakukan di daerah hilir, sungai Cidurian merupakan sungai besar yang hulu nya terdapat di Bogor. Sungai Cidurian melintasi Kabupaten Tangerang, lalu ke Serang. Sehingga pencemaran yang terjadi di Sungai Cidurian ini selain berasal dari pabrikpabrik serta masyarakat disekitar hulu, terjadi pencemaran juga oleh air yang mengalir secara terus menerus dari daerah hulu sungai. Sehingga walaupun kebersihan daerah hilir dijaga namun daerah hulu tetap tidak menjaga lingkungan sungai maka sungai 
Cidurian akan tercemar airnya oleh ulah-ulah yang dilakukan oleh masyarakat dan pabrik-pabrik tersebut.

Di Kabupaten Serang sungai Cidurian mengalir melewati daerah Cikande, Binuang, Tirtayasa, Kopo dan Tengkurak. Sungai ini dimanfaatkan masyarakat untuk kehidupan rumah tangga, pertanian dan peternakan, disekitar sungai Cidurian terdapat pabrik tekstil dan pabrik kimia yang berdampak pada sungai Cidurian dimana pabrik-pabrik tersebut membuang limbah mereka ke dalam sungai Cidurian tersebut, yang seharusnya limbah tersebut tidak dibuang ke sungai. Selain dampak limbah tekstil yang dikeluarkan oleh pabrik, dampak yang dikeluarkan atau hal-hal lainnya yang dikeluarkan dari kegiatan rumah tangga masyarakat setempat juga sangat berdampak pada pencemaran sungai Cidurian ini. Dalam menjaga pencemaran lingkungan Dinas Lingkungan Hidup Kabupaten Serang membuat surat izin lingkungan yang termasuk kedalam proses pencegahan, izin lingkungan ini dibuat agar perusahaan-perusahaan yang ingin mendirikan usahanya untuk bisa tetap menjaga lingkungan dengan tidak membuang limbah secara langsung kedalam sungai tetapi harus dengan adanya pengolahan limbah agar hasil yang dikeluarkan tidak mencemari sungai Cidurian, dan juga harus adanya IPAL, Parometer, dan tenaga penanggungjawab lingkungan. Hal ini dilakukan untuk mengurangi dampak pencemaran lingkungan.

IPAL merupakan suatu pembaharuan dari penggarapan limbah yang dihasilkan oleh pabrik, seperti limbah cair. Teknologi ini mampu memisahkan pencemaran air yang dibuang ke sungai, air limbah ini akan diproses melalui teknologi IPAL ini sehingga nanti menghasilakan limbah baik yang tidak merusak lingkungan. Untuk mendapatkan IPAL yang baik, terdapat beberapa kriteria yaitu :

- Tidak memerlukan banyak perawatan

- Dalam pengunannya, aman bagi yang menggunakan

- Biaya energi yang dihasilkan sedikit

- Menghilangkan lumpur dan mengurangi produk berbahahaya (Less Product Excess)

IPAL (Instalasi Pengolahan Air Limbah) yang biasanya digunakan merupakan penggambungan dari proses pengelolaan air dari limbah. Proses pengolahan air limbah ini menggunakan teknik fisika serta kimia yang sama seperti pengolahan air bersih lainnya. Pembangunan kegiatan industri merupakan salah satu kegiatan yang ditujukan untuk mensejahterakan masyarakat. Limbah industri merupakan salah satu limbah yang sering menjadi masalah karena limbah industri jika tidak dikelola dengan baik dapat merusak lingkungan. Limbah industri menghasilkan limbah yang memiliki bentuk cair, gas maupun padat. Akan tetapi, jika dikelola oleh teknologi IPAL secara baik maka limbah industri ini dapat dimanfaatkan kembali dan memberikan dampak baik terhadap lingkungan

Selain terdapat surat izin lingkungan, pihak dinas lingkungan hidup juga memiliki surat dokumen lingkungan yang isinya data-data tentang bahwa setiap perusahaaan yang didirikan disekitar Sungai Cidurian tidak akan melakukan pencemaran serta bukti legalitas bahwa pabrik terkait tidak mencemari lingkungan terutama pada sungai Cidurian ini, setelah adanya proses pencegahan menurut DLH Kabupaten Serang terdapat proses pengendalian, dipengendalian tersebut adanya pengawasan, pengawasan ini untuk menerapkan izin yang dibuat oleh DLH.

Pemantauan kebijakan lingkungan itu melakukan sample air sungai yang dimana pihak DLH mengambil air yang sudah menghitam untuk dibawa ke laboratorium agar dicek kadar air tersebut, pengambilan sampel ini dilakukan di 
Jembatan Maja, Kopo, Jembatan Cikande, Desa Binuang, Bakung, Mekarsari hingga Tanara. Sampel ini dilakukan untuk mengevaluasi terjadi perubahan terhadap sungai atau tidak dan dilakukan sebagai pemantauan. Selanjutnya adanya penanganan intensif, jika perusahaan tersebut sudah tebukti tercemar maka ada penanganan yang intensif yang dilakukan oleh pihak DLH

Pencegahan pencemaran lingkungan diatur dalam Peraturan Pemerintah Nomor 82 tahun 2001. Pengawasan ini tidak bisa dilakukan atau dipantau dalam waktu yang setiap saat oleh pihak DLH Kabupaten Serang, maka dari itu DLH Kabupaten Serang melakukan adanya saran dan masukan bagi Dinas Lingkungan Hidup ini untuk mendengar keluh kesah yang dirasakan masyarakat terutama pada perkembangan Sungai Cidurian tersebut. Tidak normalnya warna air yang terdapat disuatu sungai menandakan terdapat polusi di sungai tersebut. Warna air dapat terbagi menjadi (true colour) yang terjadi karena adanya bahan-bahan yang larut, serta warna semu (apparent colour), yang disebabkan karena adan

ya bahan terlarut dan koloid. Bau air yang tercium dapat dihasilkan oleh sumber air tersebut. Bau pada air dapat dijadikan tolak ukur bahwa air tersebut tercemar. Air yang baik tidak memiliki rasa atau bau, dan memiliki Ph yang normal maka ketika air terdapat bau serta rasa air tersebut dapat dikatakan telah terdapat larutan garam.

Dalam melakukan pengawasan tentang pencemaran lingkungan DLH Kabupaten Serang melakukan tiga hal yaitu Teguran, Sanksi Administrasi dan Pencabutan Izin. Dalam hal ini, jika terdapat pabrik-pabrik yang terbukti mencemari lingkungan maka tahap awal akan dilakukan peneguran terhadap pabrik tersebut, setelah dirasa teguran tidak cukup maka akan dilakukan sanksi administrasi yang kelanjutannya akan terdapat pencabutan izin pendirian industri. Dalam data 2018 terdapat tiga industri yang berdekatan dengan Sungai Cidurian. Dalam beberapa waktu sudah banyak warga sekitaran sungai cidurian yang memberi masukan bahwa sungai menghitam dan dirasa sungai tersebut sudah tercemar oleh pabrik tekstil tersebut yang dimana kemungkinan pabrik-pabrik tersebut membuang limbahnya secara langsung kesungai dan tidak diolah terlebih dahulu. Maka dari itu sungai Cidurian tercemar. Sungai Cidurian ini merupakan sungai yang digunakan oleh banyak hal seperti PDAM, Peternakan, Pengairan dan MCK Masyarakat tetapi tidak adanya konservasi yang dilakukan sehingga membuat makin lama sungai Cidurian ini semakin tercemar.

Di tahun 2018, terdapat pabrik yang mencemari sungai Cidurian yang menyebabkan limbah pabrik tersebut mencemari sungai Cidurian karena tidak tertampungnya debit limbah oleh pabrik tersebut, hal ini menjadikan sungai Cidurian tampak menghitam dan tercemar. Pencemaran sungai Cidurian oleh pabrik tekstil ini dituntut oleh masyarakat setempat karena merugikan masyarakat. Pihak DLH Kabupaten Serang segera menangani pabrik tersebut dan mengadakan uji sampel air yang dijadikan acuan untuk menindaklanjuti pabrik tersebut. Kejadian tersebut dirasakan DLH Kabupaten Serang sebagai kesalahan besar karena lalai dalam mengawasi pabrik-pabrik disekitar sungai Cidurian. DLH Kabupaten Serang segera menindaklanjuti pabrik tersebut dengan menutupnya secara sementara sampai pabrik tersebut dapat mengatasi kelalaian yang mereka lakukan, dan memberi jangka waktu agar pabrik tersebut dapat mengatasi kesalahan yang mereka lakukan atau pabrik mereka akan ditutup, karena kelalaian tersebut kini pabrik itu sudah memiliki alat yang digunakan untuk membuang air limbah pabrik agar tidak mencemari Sungai Cidurian 
DLH Kabupaten Serang ingin menerapkan kebijakan yang berdasarkan pada Enviromental Governance akan tetapi masih terhalang beberapa hal diantaranya ;

1. Anggaran

Anggaran yang diberikan oleh pemerintah pusat hanya berkisar sebesar Rp. 400.000.000,00 selama setahun, hal ini dirasakan oleh PEMKAB kurang karena PEMKAB Serang menginginkan diadakannya alat otomatis untuk memantau kegiatan yang dilakukan oleh industri-industri di sekitar Sungai Cidurian sehingga jika terjadi pencemaran atau kelalaian yang dilakukan oleh industri tersebut dapat langsung teratasi.

2. Kurang Perhatian

Banyaknya sungai yang mengitari Kabupaten Serang menjadikan Sungai Cidurian kurang diperhatikan oleh pemerintah padahal sungai Cidurian merupakan salah satu sungai besar yang digunakan oleh banyak kegiatan yang dilakukan oleh masyarakat. Dimaksudkan bahwa dari PEMKAB Serang tidak mengadakan kegiatan rutin untuk membersihkan sungai Cidurian, padahal sampah-sampah di Sungai Cidurian sangat banyak dan dapat menghambat aliran air serta membuat kotor sungai sehingga menjadikan sungai Cidurian ketika musim kemarau tampak menghitam

3. Kesadaran Masyarakat

Kesadaran masyarakat merupakan faktor penting jika faktor-faktor yang lain sudah terpenuhi. Masyarakat di sekitar sungai Cidurian masih kurang sadar akan pentingnya menjaga kestabilan dan kebersihan air sungai karena masyarakat sekitar sungai Cidurian menggunakan air di Sungai Cidurian secara sembarangan tanpa konservasi. Masyarakat menggunakan sungai Cidurian untuk kehidupan sehari-hari terutama MCK, membuang sampah sembarangan hal ini membuat sungai Cidurian mudah tercemar karena adanya limbah yang dihasilkan oleh masyarakat. Masyarakat juga menebang pohon-pohon di sekitaran Sungai Cidurian karena merasa tanah yang digunakan untuk menanam pohon tersebut merupakan tanah pribadi milik warga, padahal pohon-pohon tersebut dapat digunakan sebagai resapan air akan tetapi masyarakat justru mendirikan bangunan sehingga resapan air menjadi terganggu

Sungai Cidurian akan tampak menghitam ketika musim kemarau, kurangnya debit air yang ada saat musim kemarau membuat hal ini dapat terjadi, selain itu tidak adanya resapan air dapat menyebabkan debit air berkurang dan menjadikan sungai Cidurian menghitam.

DLH Kabupaten serang bersama pemerintahan pusat dalam mengatur pencemaran lingkungan berpacu pada UU 32 tahun 2009 tentang Perlindungan dan Pengelolaan Lingkungan Hidup (PPLH) menurut UU no 32 tahun 2009 pasal 1 ayat (2) adalah upaya sistematis dan terpadu yang dilakukan untuk melestarikan fungsi lingkungan hidup dan mencegah terjadinya pencemaran dan/atau kerusakan lingkungan hidup yang meliputi perencanaan, pemanfaatan, pengendalian, pemeliharaan, pengawasan, dan penegakan hukum.

\section{Kesimpulan}

Tercemarnya Sungai Cidurian ini disebabkan oleh pabrik-pabrik tekstil yang ada didaerah sekitar Sungai Cidurian sehingga dapat diketahui bahwa sebenarnya DLH Kabupaten Serang telah memberikan dan mengeluarkan kebijakan untuk pabrik-pabrik yang mencemari air sungai, dengan adanya kebijakan tersebut terlihat jelas bahwa DLH 
Kabupaten Serang sangat menjaga sungai yang ada di Kabupaten Serang. Akan tetapi masih terdapat pencemaran yang ada di sungai Cidurian yaitu masih ada beberapa pabrik yang membuang limbah ke sungai Cidurian tersebut, namun ada beberapa kendala ketika DLH Kabupaten Serang ini ingin menerapkan kebijakan Good Enviromental Governance yaitu diantaranya kurangnya anggaran sehingga mereka tidak dapat membeli alat yang memang diperuntukkan untuk memantau debit air limbah yang masuk ke air sungai. Dan memerlukan anggaran besar yang harus dikeluarkan untuk membeli alat tersebut. Maka dari itu, kendala yang dirasakan yaitu anggaran yang tidak mencukupi, kurangnya perhatian dari pemerintah pusat kepada pemerintahan Kabupaten terhadap pengawasan Sungai Cidurian. Yang terakhir ialah kurangnya kesadaran masyarakat akan hidup sehat, hal ini disebabkan masyarakat sekitar yang menggunakan air sungai Cidurian untuk keperluan hidup sehari-hari mereka padahal air tersebut sudah tercemar dan dapat diperhatikan bahwa sungai Cidurian tersebut sudah tidak baik digunakan bagi kesehatan diri mereka. Dalam menerapkan Good Enviromental Governance membutuhkan hubungan yang saling bekerjasama yang sinegis antara pemerintah, masyarakat maupun pihak swasta sehingga jika ketiga faktor tersebut sudah terpenuhi dengan baik, Good Enviromental Governance akan tercapai dan jika ketiga faktor tersebut tidak terpenuhi, makan Good Enviromental Governance tidak dapat terlaksana.

\section{Referensi}

Belladona, M. (2017). Analisis Tingkat Pencemaran Sungai Akibat Limbah Industri Karet Di Kabupaten Bengkulu Tengah. Seminar Nasional Sains Dan Teknologi Fakultas Teknik Universitas Muhammadiyah Jakarta, November, 1-2.

Caiden, G. E. (1994). Management 2000. International Journal of Public Administration. https:// doi.org/10.1080/01900699408524916

Faisah, N., \& Prianto, A. L. (2015). Good Environmental Governance (Studi Kasus Pengelolaan Taman Macan Di Kota Makassar. Otoritas: Jurnal Ilmu Pemerintahan, 5(2). https://doi.org/10.26618/ojip.v5i2.122

Hikmawan, M. D., Ika Indriyany, A., \& Ma'asan Mayrudin, Y. (2019). Environmental Movement Against Mining Exploration in Bojonegara Serang Banten.

Hikmawan, M. D., Indriyany, I. A., \& Mayrudin, Y. M. (2019). Environmental Movement Against Mining Exploration in Bojonegara Serang Banten. https://doi.org/https://doi.org/10.2991/icdesa-19.2019.57

Mardiana, S. Y. (2019). Wilayah Gerak Earth Hour Menjadi Sarana Pemerintah dan Swasta Meraih Dukungan Publik. International Journal of Demos, 1(3), 394-406.

Mardikawati, D., \& Yogyakarta, U. M. (2018). Pencemaran Lingkungan di Sungai Dawe Akibat Kegiatan Pembuangan Limbah Industri Pabrik Tahu. May.

Maulana, R. Y. (2020). Collaborative Governance in the Implementation of EGovernment-Based Public Services Inclusion in Jambi Province, Indonesia. Journal of Governance, 5(1), 91-104. https:/ / doi.org/10.31506/jog.v5i1.7317 
Volume 2, Issue 3, December 2020

http://hk-publishing.id/ijd-demos/index

Nopyandri, N. (2014). Penerapan Prinsip Good Enviromental Governance Dalam Rangka Perlindungan Dan Pengelolaan Lingkungan Hidup. Jurnal Ilmu Hukum Jambi, 5(2), 43278.

Permatasari, D. N., \& Yogyakarta, U. M. (2018). Penerapan Konsep Good Environmental Governance Dalam. May.

Putu, N. I., \& Yulia, D. (2007). Penerapan Prinsip-Prinsip Good Environmental Governance Dalam Pengelolaan Ruang Terbuka.

Sawir, M., \& Hafid, S. (2020). Effectiveness of The Agriculture and Food Department in Developing The Food Security Sector in Yalimo Regency. Journal of Governance, 5(1), 105-122. https://doi.org/10.31506/jog.v5i1.7814

Solikhin, A. (2017). Menimbang Pentingnya Desentralisasi Partai Politik di Indonesia. Journal of Governance, 2(1), 36-64. https:// doi.org/10.31506/jog.v2i1.2120 